\title{
The Strategy of Salt Business Development: A Case Study in Sumenep, Indonesia
}

\author{
Rika Diananing ${ }^{1}$, Amilia Destryana ${ }^{1, *}$, Ribut Santosa ${ }^{1}$, Noor Illi Mohamad Puad ${ }^{2}$, and \\ Agustine Christela Melviana ${ }^{3}$ \\ ${ }^{1}$ Faculty of Agriculture, Jl. Raya Sumenep-Pamekasan, Wiraraja University, \\ Sumenep 69451, Indonesia \\ ${ }^{2}$ Kulliyyah of Engineering, International Islamic University Malaysia \\ P.O. Box 10, 50728 Kuala Lumpur, Malaysia \\ ${ }^{3}$ School of Life Sciences and Technology, Bandung Institute of Technology, Jl. Ganesha No. 10, \\ Bandung 40132, West Java, Indonesia
}

\begin{abstract}
Sumenep is one of the salt producers in Indonesia. The problem experienced by farmers is the production of salt using evaporation by solar energy that depends on the weather and the low price, caused by worse business management. Salt is a potential commodity, because its market is still wide open. This research aims to develop the salt production method and development strategy of salt business in Sumenep Regency by using SWOT analysis. The result of the analysis concludes that the priority of salt development business strategy in Sumenep Regency are: i) Geoisolator technology application strategy to produce good quality of salt; ii) cooperation strategy in group mechanism to build power and increasing the bargaining value of the farmers; iii) capital strengthening strategy through partner cooperatives; iv) broader marketing management management strategies to industrial salt user sectors.
\end{abstract}

Keywords: Environmental friendly, gap of technology in farmer salt, Geo-isolator, increase salt productivity, increase salt quality

\section{Introduction}

Coastal and marine areas have a very high potential to be developed, therefore in the management of marine resources and fisheries coastal and marine areas need to be carefully planned and in accordance with the characteristics of the region. Based on data from the Department of Marine Affairs and Fisheries of Sumenep Regency, the largest production of the last $5 \mathrm{yr}$ in 2012 amounted to $232409.27 \mathrm{t}$.

The large number of production that contribute greatly to the national production has not been able to improve the welfare of farmers [1]. The process of making salt is generally done by the method of evaporation of seawater with solar energy, so that the minerals in it settles as desired. Another way is by the method of evaporation of seawater / brine / brine in fuel, electrodialysis and salt mining from salt rock. Traditional folk salt is generally made by drawing sea water, then incorporating evaporation fields to produce crystals. There are gaps in technology so resulting salt is still crunchy, contains low $\mathrm{NaCl}$, a lot of

\footnotetext{
*Corresponding author: amiliadestryana@gmail.com or amiliadestryana@wiraraja.ac.id
} 
soil/low impurities, dull color, high water content. Meanwhile, in terms of marketing system. One concern related to seawater desalination addresses the disposal of the concentrated saline, resulting from seawater desalination, which could cause serious environmental problems in the marine ecosystem [2-8].

There are gap of technology so resulting salt is still crunchy, contain low $\mathrm{NaCl}$, a lot of soil /low impurities, dull color, high water content. Meanwhile, in terms of marketing system, salt is weak and vulnerable position because it does not have direct market access. The integration of seawater desalination and sea salt production has been reported in the world $[9,10]$.

Most salt ponds around the Indonesia are being either abandoned or converted for aquaculture, mainly due to decreases in the profitability of salt production in recent decades [11]. The new method is needed to increase the profitability of salt production, such as desalination to obtain the frewshwater and salt production [12], ion-exchange membrane electrodialysis [13], osmosis and nanofiltration [14]. The research objectives are i) to know the method of salt production in Sumenep Regency and ii) to determine the strategy of salt people business development in Sumenep regency.

\section{Methods}

This research was conducted in the salt center of Sumenep Regency, Indonesia with primary data collection technique by giving questionnaire and interview and secondary data with article or data.

\subsection{Population and sampling}

In this study, the population is the stakeholders, especially the salt farmers in accordance with the extent of land they are working on. Based on data from the Department of Marine and Fisheries, 2015, salt ponds spread in Sumenep Regency are presented in the table below.

Table 1. Land area of public salt production

\begin{tabular}{|c|c|c|c|c|}
\hline No & Districts & Labors & Land Area Production (ha) & Land Area (\%) \\
\hline 1 & Gapura & 445 & 302.7 & 15.57 \\
\hline 2 & Dungkek & 239 & 143.5 & 7.38 \\
\hline 3 & Pragaan & 390 & 257.96 & 13.25 \\
\hline 4 & Saronggi & 576 & 338.75 & 17.42 \\
\hline 5 & Kalianget & 787 & 495.05 & 25.46 \\
\hline 6 & Kota & 8 & 4.72 & 0.24 \\
\hline 7 & Giligenting & 506 & 285.54 & 13.14 \\
\hline 8 & Ra'as & 109 & 65.84 & 3.27 \\
\hline 9 & Sapeken & 100 & 50.76 & 2.61 \\
\hline 10 & Arjasa & 49 & 24.5 & 1.26 \\
\hline \multirow[t]{2}{*}{11} & Talango & 10 & 7.59 & 0.39 \\
\hline & Total & 3222 & 1977.21 & 100 \\
\hline
\end{tabular}

Source: Dinas Kelautan dan Perikanan [15] 


\subsection{Equations and mathematics}

Sampling conducted in this study using purposive sampling method is the selection of respondents conducted deliberately in the District Kalianget, District Gapura and District Saronggi. In this study, to determine the number of samples representing the population used the Slovin Umar formula [3] in Equation (1):

$$
n=\frac{(1) \mathrm{N}}{1+N e^{2}}
$$

\footnotetext{
Explanation:

$\mathrm{N}=$ sample size

$\mathrm{N}=$ population size

$\mathrm{E}=$ critical value
}

In this study the number of customer populations with the desired error limit is $10 \%$. Based on the above formula, the samples taken in this study as in Table 2.

The method of analysis used to know the strategy of salt business development using SWOT analysis model which is one method to describe the condition and evaluate a problem, project or business concept based on internal factor and external factor that is Strengths, Weakness, Opportunities and Threats. This method is most often used in business evaluation methods to find the strategy to be performed. SWOT analysis only describes the situation that occurs not as a problem solver.

Table 2. Data of population and sample

\begin{tabular}{|c|l|c|c|c|c|}
\hline \multirow{2}{*}{ No } & \multirow{2}{*}{ Districts/Area } & \multicolumn{2}{|c|}{ Population } & \multicolumn{2}{c|}{ Sample } \\
\cline { 3 - 6 } & Geoisolator & Traditional & Geoisolator & Traditional \\
\hline 1 & Gapura/Gersik Putih & 12 & 16 & 7 & 8 \\
\hline 2 & $\begin{array}{l}\text { Saronggi/ } \\
\text { Kebundadap Barat }\end{array}$ & 9 & 18 & 6 & 9 \\
\hline 3 & $\begin{array}{l}\text { Saronggi/ } \\
\text { Kebundadap Timur }\end{array}$ & 2 & 2 & 1 & 1 \\
\hline 4 & Saronggi/Saroka & 2 & 1 & 1 & 0 \\
\hline 5 & $\begin{array}{l}\text { Kalianget/ } \\
\text { Karanganyar }\end{array}$ & 15 & 14 & 9 & 4 \\
\hline 6 & $\begin{array}{l}\text { Kalianget/ } \\
\text { Marengan Laok }\end{array}$ & 3 & 15 & 1 & 8 \\
\hline 7 & $\begin{array}{l}\text { Kalianget/ } \\
\text { Pinggirpapas }\end{array}$ & 4 & 14 & 1 & 7 \\
\hline 8 & Kalianget/Kertasada & 8 & 6 & 2 & 3 \\
\hline & Total & 55 & 86 & 28 & 40 \\
\hline
\end{tabular}

Source: Processed Data, 2016 


\section{Results and Discussion}

\subsection{Potential salt pond in Sumenep Regency}

Potential salt pond in Sumenep Regency spread in several areas, among others: Pragaan Sub-district, Giligenting Sub-district, Saronggi Sub-District, Kalianget Sub-District, Gapura Sub-District, Dungkek Sub-district, Talango Sub-District, Raas Sub-District, Arjasa District and Kangayan Sub-District. Salt pond in Kab. Sumenep by ownership status can be distinguished into private/public property and belongs to PT. Garam Persero.

Table 3. Data of land area of salt regency of Sumenep

\begin{tabular}{|c|c|c|}
\hline No & Land ownership & Land area (ha) \\
\hline 1 & Public & 2068 \\
\hline 2 & PT. Garam Persero & 3300 \\
\hline & Total & 5368 \\
\hline
\end{tabular}

Source : Dinas Kelautan dan Perikanan, [15]

Productivity salt from public land area in the last $5 \mathrm{yr}$ the samples taken in this study as in Table 4

Table 4. Production of salt in Sumenep regency 2011 to 2015

\begin{tabular}{|l|c|c|c|c|c|}
\hline \multirow{2}{*}{ No } & \multicolumn{5}{|c|}{ Production (t) } \\
\cline { 2 - 6 } & $\mathbf{2 0 1 1}$ & $\mathbf{2 0 1 2}$ & $\mathbf{2 0 1 3}$ & $\mathbf{2 0 1 4}$ & $\mathbf{2 0 1 5}$ \\
\hline 1 & 160683.82 & 232409.27 & 185385.54 & 292051.54 & 236117.97 \\
\hline
\end{tabular}

Source: Dinas Kelautan dan Perikanan [15]

\subsection{Analysis of study}

\subsubsection{Identification analysis of internal and external factors $(S, W, O, T)$}

In the identification of internal factors consists of two parts of strengths and weaknesses (weaknesses) that exist in the internal development of salt public business in Sumenep Regency with the description as follows:

1. Strengths
a. Experienced workers
b. There is no salt substitution yet
c. Simple production equipment
d. Raw material production abundant
e. Potential land

2. Weakness
a. Lack of facilities and infrastructure
b. The bargaining position of salt farmers is weak
c. Lack of capital
d. Lack of technology
e. Limited financial services 
The identification of external factors consists of two parts, Opportunity and Threat that exist in the development of salt public business in Sumenep Regency, Indonesia with the following description:

3. Opportunity
a. High and unfulfilled market demand
b. Relatively high selling prices in certain seasons
c. Government policy support
d. Technological innovation iodine salt development
e. Accompaniment

4. Threads
a. Free market
b. Higher quality salt production is circulating within the same consumer region
c. Business security
d. Weather conditions
e. Wholesaler

\subsubsection{Matrix of quality IFAS and EFAS}

In performing the SWOT analysis, it is necessary to consider the internal weighting matrix of Factor Analysis Strategy (IFAS) and External Factor Analysis (EFAS). Observations and interviews with stakeholders of IFAS matrix identification can be seen in Table 5 and identification of EFAS matrix presented in Table 6

Table 5. Matrix of IFAS of salt public business in Sumenep

\begin{tabular}{|l|l|c|c|c|}
\hline No & \multicolumn{1}{|c|}{ Strategic Internal Factor } & $\begin{array}{c}\text { Quality } \\
(\mathbf{a})\end{array}$ & $\begin{array}{c}\text { Rating } \\
\text { (b) }\end{array}$ & $\begin{array}{c}\text { Quality vs } \\
\text { Rating (axb) }\end{array}$ \\
\hline & Strengths & & & \\
\hline 1 & Experienced workers & 0.197 & 4 & 0.788 \\
\hline 2 & There is no salt substitution yet & 0.196 & 4 & 0.784 \\
\hline 3 & Simple production equipment & 0.198 & 4 & 0.72 \\
\hline 4 & Raw material production abundant & 0.213 & 4 & 0.852 \\
\hline 5 & Potential land & 0.197 & 4 & 0.788 \\
\hline & Total & 1.000 & 19 & \\
\hline & Weakness & & & \\
\hline 1 & Lack of facilities and infrastructure & 0.182 & 3 & 0.546 \\
\hline 2 & $\begin{array}{l}\text { The bargaining position of salt farmers } \\
\text { is weak }\end{array}$ & 0.213 & 4 & 0.852 \\
\hline 3 & Lack of capital & 0.214 & 4 & 0.856 \\
\hline 4 & Lack of technology & 0.198 & 3 & 0.594 \\
\hline 5 & Limited financial services & 0.194 & 3 & 0.582 \\
\hline & Total & 1.000 & 17 & \\
\hline
\end{tabular}

Source: Processed data, 2016 
Table 6. Matrix of EFAS of salt public business in Sumenep

\begin{tabular}{|l|l|l|l|l|}
\hline No & \multicolumn{1}{|c|}{ Strategic Internal Factor } & \multicolumn{1}{|c|}{ Quality (a) } & \multicolumn{1}{c|}{$\begin{array}{c}\text { Rating } \\
(\mathbf{b})\end{array}$} & $\begin{array}{c}\text { Quality vs Rating } \\
\text { (axb) }\end{array}$ \\
\hline Opportunity & & 3 & 0.645 \\
\hline 1 & $\begin{array}{l}\text { High and unfulfilled market } \\
\text { demand }\end{array}$ & 0.215 & 3 & 0.57 \\
\hline 2 & $\begin{array}{l}\text { Relatively high selling prices in } \\
\text { certain seasons }\end{array}$ & 0.190 & 3 & 0.591 \\
\hline 3 & Government policy support & 0.197 & 3 & 0.621 \\
\hline 4 & $\begin{array}{l}\text { Technological innovation iodine } \\
\text { salt development }\end{array}$ & 0.207 & 3 & 0.573 \\
\hline 5 & Accompaniment & 0.191 & 15 & \\
\hline & Total & 1.000 & 2 & 0.376 \\
\hline Thread (s) & & 2 & 0.412 \\
\hline 1 & Free market & 0.188 & 2 & 0.356 \\
\hline 2 & $\begin{array}{l}\text { Higher quality salt production is } \\
\text { circulating within the same } \\
\text { consumer region }\end{array}$ & 0.206 & 2 & 0.663 \\
\hline 3 & Business security & 0.178 & 2 & 0.412 \\
\hline 4 & Weather conditions & 0.221 & 3 & \\
\hline 5 & Wholesaler & 0.206 & 2 & 11 \\
\hline & Total & 1.000 & & \\
\hline
\end{tabular}

Source: Processed data, 2016

\subsubsection{Strategy alternative formula}

The alternative strategy is based on the interaction of internal factors and external factors obtained based on the results of the analysis. Formulation of alternative salt business strategy in Sumenep Regency presented in Table 7.

From the table of matrix in Table 7, with strengths, weaknesses, opportunities and threats can be described as follows,

\section{S-O Strategy}

a. Encourage increased production through extensification to produce standard quality salts according to market needs. This strategy is carried out by utilizing the newly available labor force and potential untapped land. At the same time the development of new processing and innovation technologies for long-time laborers and self-sustaining production land to direct iodized salt production by utilizing financial / banking services. Implementation of this strategy can be done by extensification of land that produces salt without iodine according to quality standards so far. With the strength of the land area and the availability of sufficient labor then the implementation of this strategy is very possible to be applied so that the opportunity to reach the market and increase production volume in the short term is very potential can be achieved.

b. Intensification of capacity building activities in marketing management. This strategy is one effort that aims to optimize the utilization of opportunities for development of professional salting technology in order to enter the era of tight market competition in the future. Training programs, internships, pilots and comparative studies are essential to improve business-oriented business management skills. Amount one of the key opportunities associated with seasonal variability is the price at which certain seasons of high salt prices can be exploited by developing marketing management capabilities. 
II. W-O Strategy

Maximize the assistance given to the farmers to improve accessibility of some of the production and potential areas and to improve the quality of human resources, especially in marketing management so that the selling price of salt production as much as possible can be achieved. The maximization of government assistance in salt development programs should be well targeted and not only to form the physical aid areas in the form of facilities and facilities but should include improving the quality of human resources related to marketing. Improved quality allows to exploit potential opportunities such as temporal fluctuations in prices through marketing management and production rhythms with the highest selling price.

III. S-T Strategy

Improving access to market information and to the short-term context the quantity of salt production using traditional technology is maximized by utilizing the remaining potential land area to dominate the market, especially unmet demand. This strategy is strived as soon as possible in order to excel in the competition so that the threat of free competition can be avoided. Production of salt with sufficient quantity and quality allows for market expansion in areas where competitors have not reached it so that the projection and expansion of market information is still running and superior in the speed of controlling the market or consumer.

IV. W-T Strategy

Encourage accelerated improvement of human resource capacity and other resource utilization including financial institution services to compete in the local and regional salt industry. This strategy should be synergistic and simultaneous so that salt development efforts can avoid threats with all the weaknesses they have. Weaknesses in the form of weak human resources must be addressed through intensification of training activities and comparative studies so that the insights and skills of the farmers and salt entrepreneurs are able to compete in a tight competition especially with the implementation of free market in the future.

Table 7. Matrix of SWOT of development strategy salt business in Sumenep.

\begin{tabular}{|c|c|c|}
\hline EFAS & $\begin{array}{l}\text { Strengths } \\
\text { a. Experienced workers } \\
\text { b. There is no salt substitution yet } \\
\text { c. Simple production equipment } \\
\text { d. Raw material production } \\
\text { abundant } \\
\text { e. Potential land }\end{array}$ & $\begin{array}{l}\text { Weakness } \\
\text { a. Lack of facilities and } \\
\text { infrastructure } \\
\text { b. The bargaining position } \\
\text { of salt farmers is weak } \\
\text { c. Lack of capital } \\
\text { d. Lack of technology } \\
\text { e. Limited financial } \\
\text { services }\end{array}$ \\
\hline $\begin{array}{l}\text { Opportunity } \\
\text { a. High and unfulfilled } \\
\text { market demand } \\
\text { b. Relatively high selling } \\
\text { prices in certain seasons } \\
\text { c. Government policy } \\
\text { support } \\
\text { d. Technological } \\
\text { innovation iodine salt } \\
\text { development } \\
\text { e. Accompaniment }\end{array}$ & $\begin{array}{l}\text { S-O STRATEGY } \\
\text { a. Encourage increased } \\
\text { production through } \\
\text { extensification to produce } \\
\text { standard quality salts } \\
\text { according to market needs } \\
\text { b. Intensification of capacity } \\
\text { building activities in } \\
\text { marketing management. }\end{array}$ & $\begin{array}{l}\text { W-O STRATEGY } \\
\text { Maximize the assistance } \\
\text { given to the farmers to } \\
\text { improve accessibility of } \\
\text { some of the production and } \\
\text { potential areas and to } \\
\text { improve the quality of } \\
\text { human resources }\end{array}$ \\
\hline & & \\
\hline
\end{tabular}

(Continued on next page) 
Table 7. Continued

\begin{tabular}{|c|c|c|}
\hline $\begin{array}{l}\text { Threads } \\
\text { b. Free market } \\
\text { c. Higher quality salt } \\
\text { production is circulating } \\
\text { within the same consumer } \\
\text { region } \\
\text { d. Business security } \\
\text { e. Weather conditions } \\
\text { f. Wholesaler }\end{array}$ & $\begin{array}{l}\text { S-T STRATEGY } \\
\text { Improving access to market } \\
\text { information and to the short- } \\
\text { term context the quantity of salt } \\
\text { production using traditional } \\
\text { technology is maximized by } \\
\text { utilizing the remaining } \\
\text { potential land area to dominate } \\
\text { the market, especially unmet } \\
\text { demand }\end{array}$ & $\begin{array}{l}\text { W-T STRATEGY } \\
\text { Encourage accelerated } \\
\text { improvement of human } \\
\text { resource capacity and other } \\
\text { resource utilization including } \\
\text { financial institution services } \\
\text { to compete in local and } \\
\text { regional salt industry. }\end{array}$ \\
\hline
\end{tabular}

\section{Conclusion}

Modern methods based on geo-isolator can accelerate the production of local salt because the evaporation process is much more perfect by using a pool container using plastic, the salt produced is much more. The salt productivity by using a $100 \%$ Geoisolator is much greater than in the traditional way. Comparison of salt production per hectare using traditional methods can only produce $60 \mathrm{t}$ to $80 \mathrm{t}$ once harvested. But with Geoisolator harvest salt per hectare can reach $120 \mathrm{t} \mathrm{ha}^{-1}$ to $140 \mathrm{t} \mathrm{ha}^{-1}$. Community salt development strategy in Sumenep Regency using aggressive strategy that is by utilizing power to exploit opportunities by increasing productivity and technology to increase profit and expand marketing network and innovate in processing and production of salt.

\section{References}

1. I. Ihsannudin, S. Pinujib, S. Subejo, B.S. Bangko. Econ. Dev. Analysis J. 5,4:395409(2016). [in Bahasa Indonesia] https://journal.unnes.ac.id/sju/index.php/edaj/article/view/22177

2. H. Wang H, X. Xu, G Zhu. Sustainability. 7,8:10078-10097(2015). https://www.mdpi.com/2071-1050/7/8/10078

3. D.A. Roberts,E.L. Johnston, N.A. Knott. Water Res.44,18:5117-5128(2010). https://www.sciencedirect.com/science/article/pii/S0043135410002903

4. S. Lattemann S, T. Höpner. Desalination. 220,1-3:1-15(2008). https://doi.org/10.1016/j.desal.2007.03.009

5. J.J. Sadhwani, J.M. Veza, C. Santana. Desalination. 185,1-3:1-8(2005). https://www.sciencedirect.com/science/article/pii/S0011916405006041

6. G.L.M.V. Medeazza. 185,1-3:57-70(2005). https://www.sciencedirect.com/science/article/pii/S0011916405006089

7. R. Einav, F. Lokiec. Desalination. 156,1:79-85(2003). https://www.academia.edu/download/49616404/Environmental_aspects_of_a_desali nation_20161015-6177-txj6wp.pdf

8. A. Antonites. J. Anthropol Archaeol. 44:31-42(2016). https://www.sciencedirect.com/science/article/pii/S0278416516300976

9. A. Ravizky, N. Nadav. Desalination. 205,1-3:374-9(2007). http://atominfo.ru/files/brine/Brine\%20from\%20desalination\%20plants_06.pdf

10. Y. Tanaka, R. Ehara, S. Itoi, T. Goto. J. Memb. Sci. 222,1-2:71-86(2003). https://www.sciencedirect.com/science/article/pii/S0376738803002175

11. M.P. Dias. Waterbirds. 32,4:531-537(2009). https://bioone.org/journals/waterbirds/volume-32/issue-4/063.032.0406/Use-of-SaltPonds-by-Wintering-Shorebirds-throughout-the-Tidal/10.1675/063.032.0406.short 
12. I.G. Wenten, D. Ariono, M. Purwasasmita, Khoirudin. Integrated processes for desalination and salt production: A mini-review. AIP Conference Proceedings 1818. AIP Publishing LLC. (2017).p.20065. https://aip.scitation.org/doi/abs/10.1063/1.4976929

13. Y. Tanaka, M. Reig, S. Casas, C. Aladjem, J.L. Cortina. Desalination. 367:7689(2015).

https://www.sciencedirect.com/science/article/pii/S0011916415001897

14. Chauhan VM, Alnouri SY, Linke P, Abdel-Wahab A. Desalination. 400,2537(2016). https://www.sciencedirect.com/science/article/pii/S0011916416306683

15. Dinas Kelautan dan Perikanan. Profil Pengembangan Usaha Garam Rakyat [Profile of People's Salt Business Development]. Sumenep (2015)p.2 [in Bahasa Indonesia] 